Wildenthal, Lora. Review of Alabama in Africa: Booker T. Washington, the German Empire, and the Globalization of the New South, by Andrew Zimmerman. Central European History 44, no. 2 (2011): 344-347. doi: 10.1017/S0008938911000100.

\title{
Alabama in Africa: Booker T. Washington, the German Empire, and the Globalization of the New South. By Andrew Zimmerman. Princeton, NJ: Princeton University Press. 2010. Pp. xii + 397. Cloth \$35.00. ISBN 978-0-691-12362-2.
}

\author{
Lora Wildenthal, Rice University
}

In this book, Andrew Zimmerman takes up several classic historical themes, along with their historiographies - post-emancipation labor, the agrarian question in Imperial Germany, and the emergence of modern sociology, to name a few. He has deepened them with his own extensive original research, and fitted them together in a complex, seamless, and highly impressive book. Alabama in Africa makes these classic themes new again by showing us how they are interconnected.

The story begins with cotton. Clearly inspired by Sven Beckert's work on the global history of cotton, Zimmerman narrates how, after the abolition of serfdoms and slaveries in the U.S. South and elsewhere, agricultural owners and industrialists were searching for new modes of coercion in the new landscape of "free" [End Page 344] labor. He explains how the mechanization of cotton spinning and weaving required more, and more precise, non-mechanized labor in cotton growing. In other words, the modernization of cotton required the modernization of manual labor coercion - a key example, but only one example, of a broader pattern in industrial capitalism. In the New South, the answer came to be "Negro" sharecropping (with "Negro" in quotation marks not as an archaism, but as the label for a mythical New South worker who was naturally suited to cotton growing like no other laborer, and yet needed compulsion to express that natural aptitude). Booker T. Washington's Tuskegee Institute both accepted and sought to rework the implications of the widely accepted linkage between the "Negro" and cotton to the benefit of AfricanAmericans. The rest of the book explores a variety of efforts to turn African-American freedpeople as well as Togolese and others into this mythical New South industrial-era "Negro." As Zimmerman shows over the course of the whole book, Washington's interactions with German colonial authorities convinced him of the global importance of the "Negro" he was promoting at Tuskegee, and they drew him away from emancipatory possibilities he had once entertained. 
Zimmerman turns in chapter two to the German discussion of agricultural labor (here in sugar beets), migration, and modernization in the Prussian east, especially among members of the antifree-trade reformers in the Verein für Sozialpolitik. Racial difference was fundamental in this discussion as well, and the Verein cooperated with the Kaiserreich to promote "inner colonization" on smallhold farms as a method to immobilize a German agricultural labor force and "Germanize" Prussian Poland. Karl Marx, Gustav Schmoller, Georg Friedrich Knapp, and Max Weber among others drew connections between the Prussian east and the U.S. post-Civil War South; except for Marx, they did so to seek methods of controlling nominally free workers.

Chapter three takes up the episode of Tuskegee Institute's presence in the German colony of Togo, sponsored by the colonial administration and the Kolonial-Wirtschaftliches Komitee, a German colonial business group. Beginning in 1901, Tuskegee sent several of its own staff to Togo, and they taught their first class in 1904. Within a few years, all of the Tuskegee staff had died or returned to the U.S., but the importance of this effort resonated well beyond those persons and first years. The very establishment of the cotton schools was concomitant with the expansion of German colonial rule - they were located where German military expeditions had laid waste to villages, and prisoners and "tax workers" were forced to clear the fields used to plant cotton. Even the students were forced to attend against their will. Togolese prosperity, based on diverse, regional, and gender-patterned production and trade, decreased, against the hopes of Tuskegee staff who believed that they were bringing Africans a recipe for prosperity and "civilization." Yet Zimmerman stresses that failure to achieve the proclaimed goal of [End Page 345] promoting African prosperity did not mean that the expedition and schools were a failure. Rather, it was a success for the colonial government and for industry, and showed the "paradoxical connection of freedom and force ... in the emerging global South" (p. 172). The Tuskegee experiment in German Togo succeeded in destroying African-controlled production and consumption and in forcing Togolese men and women to work for the international industrial commodities market, and those were the goals of many, though not all, of those behind the effort.

Having established the Togo case as a key example of the globalization of the New South formula for the coercion of "free" labor, Zimmerman then turns to its afterlife. Educators, social scientists, and agricultural and industrial managers and experts cited it for years afterward as a success. Washington himself (who never visited Togo) described the Tuskegee schools there in terms that had, at best, a loose connection to actual conditions and achievements. Those praising the Tuskegee expedition to Togo either did not know about or did not want to elaborate on its cruelties and absurdities. Instead, they considered it a success because it demonstrated that blackskinned people who were not American could be made to grow cotton using New South methods, that the cotton did approximate the quality of U.S. cotton, and that cotton production did increase. The brevity and small scale of the German experiment were not important; the method was. Reformers such as E. D. Morel and Ernst Vohsen turned to Booker T. Washington, according him a new degree of international prominence as the educator who held the key to "Negro" free labor, that is, the management of racial difference in the service of capitalism. The idea of mobilizing African colonial subjects as workers in the world economy filtered into German domestic politics, turning the 1907 election in the government's favor and splitting the Social Democrats over the question of the acceptability of colonialism. It also filtered into the 
liberal internationalism of the interwar era that was spearheaded by two arch-segregationists, Woodrow Wilson and Jan Smuts.

In a final chapter, Zimmerman turns again to the thematic and personnel linkages in social science, specifically in Chicago School sociology. Max Weber, Robert E. Park, Park's teacher Georg Friedrich Knapp, and Park's student William I. Thomas, for example, all drew from one another in their research on African-Americans, Poles, peasants, and urban immigrants.

Especially Weber and Park produced a sociological, rather than biological, concept of race that sought to fix human difference and explain economic behavior in terms of ethnically or racially specific culture. In so doing, they turned repeatedly to Booker T. Washington and the Tuskegee expedition to Togo, which "brought together three of the most powerful forces in the Atlantic world - German social science, African cash cropping, and the racial political economy of the New South" (p. 248).

Those are the main lines of argument. It isn't possible to do justice to Zimmerman's detail and subtlety in sketching out the many differences of [End Page 346] opinion among the people mentioned, and changes over time in the thinking of each of these people (and the ones mentioned here are not the full cast of characters). The book deserves a wide readership, from undergraduates to advanced researchers. 